\title{
THE BIRTH OF IT IN UPPER SECONDARY EDUCATION IN NORWAY
}

\author{
Steinar Thorvaldsen and Jan Wibe \\ 1.Thorvaldsen, Section for Informatics,TromsøUniversity College; steinar@hitos.no \\ 2.Wibe, Norwegian University of Science and Technology; jan.wibe@plu.ntnu.no
}

\begin{abstract}
The first course in computer science started at "Forsøksgymnaset" (The Experimental High School) in Oslo in 1969. In 1970, it spread to three upper secondary schools (Drammen, Sogndal and Trondheim). The subject was close to mathematics, and the focus was on programming and electronic logic. FORTRAN was the programming language and the programs ran on a large computer, the Univac 1108 , located at the technical university (NTH). No relevant subject-related software was available at that time, but the class developed some powerful cases in mathematics and physics. In electronic logic, we used an electronic machine called Benjamin to do binary operations in the classroom. We can call Benjamin the first "processor" in upper secondary education in Norway. In this paper, we will show that many of the long lasting trends in the subject can be observed in the initial period itself
\end{abstract}

Key words: ICT, High School, logic simulator, Univac, Fortran

\section{SOME BACKGROUND}

The period 1960-70 was in the prime time of the space age, with the first man in space in 1961 and the first man on moon in 1969. Technology was developing very rapidly, and science and technology was in the headlines of the news and media.

In the same period, the teaching of mathematics started to change with the introduction of modern mathematics that included set theory, logic, and Boolean algebra. Some scientists even considered programming and the use of computers to become a kind of "second literacy". This was to enhance 
the intellectual power of humanity. A significant role in the future education would be the ability to write computer programs and reason on them. Combined with mathematical and linguistic concepts, this was to provide an important foundation for future generations. The computer would be more than just a technical tool in the learning process. It could possibly bring about a renovated intellectual background, a new operational setting where a child in its development could exploit organically and naturally this new machine. In this optimistic setting, computer science was to have an ability to create in the pupils an organizational, algorithmic, and operational attitude.

In Norway, "Forsøksgymnaset" applied for permission to test "Mathematics with computer science and statistics" in April 1968, and the first school committee to deal with computer science in the Norwegian Upper secondary education was established by "Gymnasrådet" on the $25^{\text {th }}$ of November 1968 with the principal, Alf Gudbrandsen as chair. Other members were the economist Eivind Barca, Aage Vestøl from "Norsk regnesentral", Alf Baltzersen from Drammen Gymnas, Arvid Amundsen from "Institutt for alkoholforskning", Jan Gram from "Forsvarets forskningsinstitutt", Herman Ruge from "Forsøksgymnaset" in Oslo and Ragnar Solvang (Ruge 2003).

The new subject should be part of mathematics and they planned the curriculum according to that perspective. Programming was a continuation of the traditional algebra that one could teach with the same goal and motivation. A practical solution was to exchange the new course in computer science with the old course in projective geometry (projeksjonstegning). The old course had two lesson-hours a week and became part of the curriculum around 1870 .

The school committee presented its first report in June 1969. This was just in time for starting up at Forsøksgymnaset with Ruge as teacher. The first class had their exams in June 1970. The final proposal from the school committee was presented in February 1972 and had the title: "Innstilling om databehandling i gymnasundervisningen". In the meantime, several other schools had started with courses in computer science. The first three were Drammen, Strinda (in Trondheim) and Sogndal upper secondary schools (gymnas). The Univac 1108 as shown in Figure 1 was the computer they used in Trondheim. 


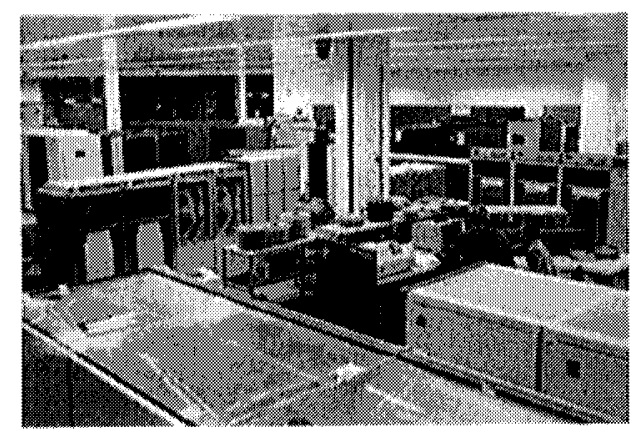

Figure 1: Univac 1108. Students in upper secondary education in Trondheim had access to such a computer at the technical university in 1970.

Very few teachers knew about computer science and programming. Because of this, Ruge arranged a seminar for teachers on the $2^{\text {nd }}$ and $3^{\text {rd }}$ of January 1970. As far as we know, this was the first course of its kind in Norway and Norwegian television even broadcasted it. The seminar was on computers and cybernetics, with practical exercises in electronic logic. The material developed during the seminar was later used by the schools. Among the participants in the seminar were Kjell Henden from Sogndal, Jan Wibe from Trondheim, Jan Ommundsen from Ris, and Per Arnstedt from Drammen. They were later to play a leading role in the further development of the curriculum. The seminar in January 1971 had also participants from Sweden ( $\AA$ ke Anderson from the Swedish "Skolöverstyrelsen", and Lars Bengtson from the department of physics at Stockholm University). In the summer of 1971, Ruge gave a lecture at the Nordic congress for mathematics and science teachers ("LMFK-kongressen") in Bergen.

\section{THE CURRICULUM}

The school committee appointed by "Gymasrådet" had a long discussion about the content of the course. Was it necessary for the students to learn programming, or could they use standard software? The conclusion was in favour of programming. The whole process of developing and testing a program would give basic skills, both in computer science and in problem solving. The committee agreed upon this.

However, what programming language should we use? There was a lot of software discussion at the time: Algol, Fortran, Basic, or the Norwegian Simula? In practice, it was not much to discuss, one had to take the one that the computer was running. 
The course should also include some of the computers own type of mathematics, some coding theory and electronic switch logic. Main items in the course content:

- About computers - classroom teaching

- Electronic logic - with exercises done on a simulator

- Programming (Fortran, Basic or Algol) - as standard mathematical teaching

- Programs with problems from some of the school subjects - mostly as group work.

The programs should be punched on cards and run on a real computer! At Strinda gymnas, Fortran was used the first year. Later, they used Basic and the programs ran on PDP-11 at Trondheim engineering college. They did this by communication and a modem on both sides. Basic was a language actually designed for schools by teachers.

\section{BENJAMIN: THE LOGIC SIMULATOR}

An important element in the plan was to learn something about how a computer was working. In 1969, transistor circuits were mass-produced as cheap microelectronics. Herman Ruge had used them in his job at the Central Institute for Industrial Research (SI). The three basic types of logical ports (AND, OR, NOT) were mounted on a small box, together with contacts, switches and signal lamps. All parts linked together with flexible cables as shown in Figure 2. It was a "Logic Simulator" and they gave it the name "Benjamin", (Ruge 1970, 2003). Herman Ruge produced a book with exercises. A small electronic company "Nortronic" put the simulator in production, with oak on the desktop and gold on the contacts. The selling price was around 500 Norwegian kroner. At Strinda gymnas, the son of the principal (Berntsen) produced a local version of Benjamin. Benjamin made its debut at the first OECD "Seminar on Computer Science in Secondary Education" in Paris, March 1970. The "Centre for Educational Research and Innovation" (CERI) arranged the seminar. 


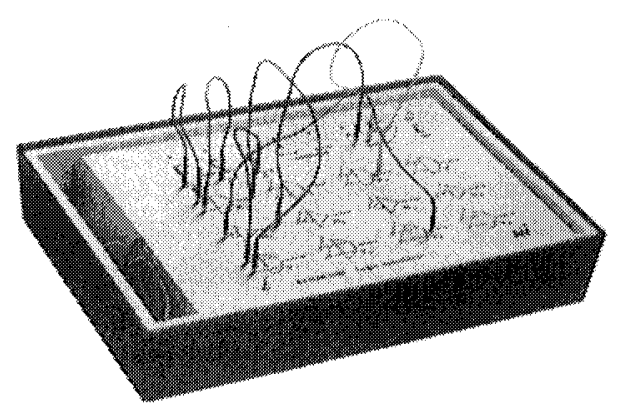

Figure 2. The logic simulator "Benjamin"

By using Benjamin, we were able to implement basic mathematics such as Boolean algebra, mathematical logic, set theory, and binary arithmetic with addition circuits. Statements of the type "If you are interested and I have time, then we may go for a walk" could be an implementation on Benjamin. The circuits also functioned as a 1-bit memory (or-element with feedback). For advanced projects, two or more machines could be linked together. It was a perfect application of modern mathematics. However, in the spring of 1972, a big debate on modern mathematics started, and as a result, most of the mathematical logic was taken out from the textbooks.

Logic simulators were not a new invention (Gardner 1968), and it probably could not be patented. Nevertheless, the Norwegian version had a very simple design and some had plans for selling many thousands of them to England using a plastic version. However, it was too expensive, so England produced its own version instead. "Nortronic" manufactured some 400 of them and even a more advanced model with shift registers, adders, and a clock. Today there are PC-programs that can simulate the logical circuits on the screen.

\section{PROGRAMMING}

At Strinda gymnas, we used the following procedure when we worked with exercises in programming, analyzed the problem using flowcharts and wrote a program on paper. Then, we handed over the written program to punch operators at the technical university and they punched out the program on special cards, one statement per card. The punching machine was expensive and very noisy. Then the cards were fed into the computer. In the next day or so, we received the results (or an error report from the compiler!). Finally, the finished program ran with different sets of data produced by the students, like lab-data from experiments in physics. 
We used the same textbook in Fortran (Selvberg 1970) as the students at the university. The next year, Strinda changed to programming in Basic. They used a terminal (teletype) and the programs ran at the technical college.

Among the examples implemented in the class at Strinda gymnas, were computations of quantities from experiments in physics, of the type we today would use a spreadsheet. We also computed the value of the number $e$ using a convergent process. One of the more ambitious projects we had was plotting of mathematical functions. There was no graphical screen, we did the drawing using printers with space and dots as in Figure 3. The final version of this program consisted of six subroutines and a total of 350 lines Fortran code. It could solve nearly all the exercises on functions in our textbooks, drawing graphs and determining all maxima, minima, zeros, and inflection points!

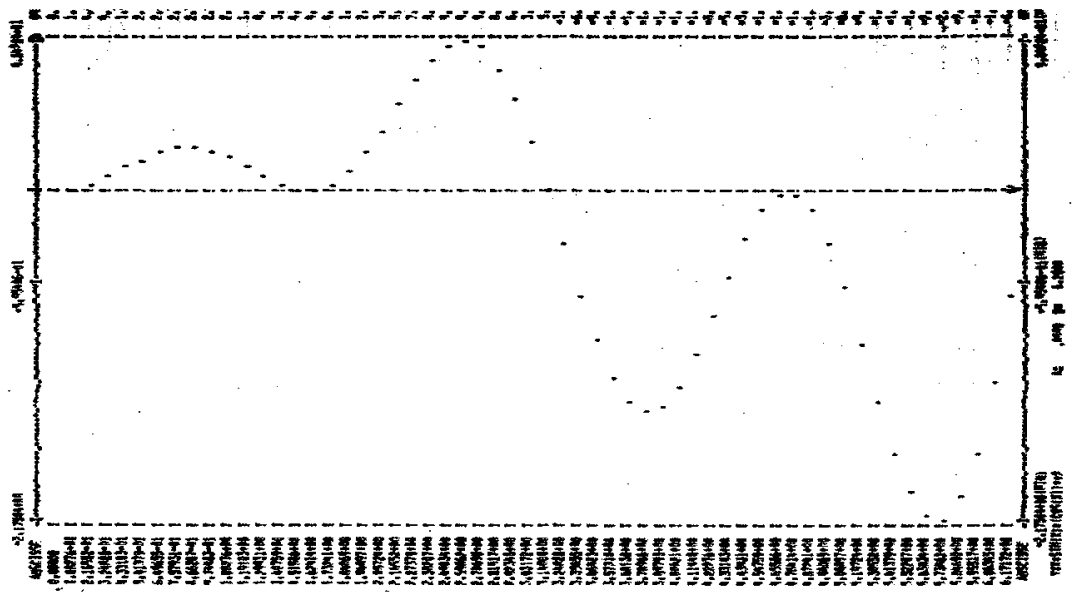

Figure 3. A programming project in function analysis was used to solve real exercises in mathematics, here a plot of the function $f(x)=\sin (x) \cdot \cos ^{2}(x)$

\section{CONCLUSIONS}

The new subject in computer science which started at "Forsøksgymnaset" in Oslo in 1969, spread rapidly to schools all over the country. In 1975, the number of students was around 1000. In the autumn of 1977, students studied computer science in 162 of the 417 upper secondary schools in Norway, close to $40 \%$. In 1983 , it was close to 250 schools and 6750 students (Ruge 2003). 
Computer science was in some items linked with modern mathematics, especially logic and set theory. However, it was also part of the science paradigm "learning by doing". We always taught the subject with some kind of local equipment in the local classroom.

In 1969, Herman Ruge designed the first digital "processor" used in the classroom. It was a logic simulator called "Benjamin" and illustrated with hands-on experience how a digital computer functioned. In 1972, a debate on modern mathematics started in the media and as a result, they eliminated most of the mathematical logic from the textbooks; hence, also "Benjamin".

At the initial stage, some universities sponsored the schools with runtime on their computers. Students were at this initial stage capable of developing far-reaching programs to meet their own educational needs, products that would have been well worth a study by the school reformers. Early in the $70 \mathrm{~s}$, the students could conduct their exercises on the computers from their classrooms via terminals. Standard programming stayed part of the school curriculum for many years.

This is all part of a general trend. To do their work, students and teachers want to have an entrance to computers at the simplest possible access level. The paradox in this rule is that computers gets more and more like boxes for the users-like black boxes. In old days, cars were also quite seldom and the function of the motor was part of the curriculum. Today, we all have cars and the physics of the motor is absent from the standard curriculum. As A.N. Whitehead said, "Civilization advances by extending the number of important operations which we can perform without thinking about them".

\section{REFERENCES}

1. Gardner, Martin: Logic Machines, Diagrams and Boolean Algebra. Dover 1968.

2. Ommundsen, Jan B. \& Wibe, Jan: Eksamensoppgaver $\mathrm{i}$ databehandling for den videregående skole. J.W. Cappelens forlag 1983.

3. Ruge, Herman: Automatisk databehandling i gymnaset, Den høgre skolen, nr.3, 1969.

4. Ruge, Herman: Øvinger i elektronisk logikk. Førsøksgymnaset i Oslo, 1970.

5. Ruge, Herman: Utvikling og reform av videregående skolematematikk. Manuscript, 2003.

6. Sølvberg, Arne: Fortran. Tapir forlag 1970.

7. Whitehead, Alfred N: An Introduction to Mathematics. Williams and Norgate 1911. 